\title{
Double Interrogation
}

\section{Robert J. MacG. Dawson}

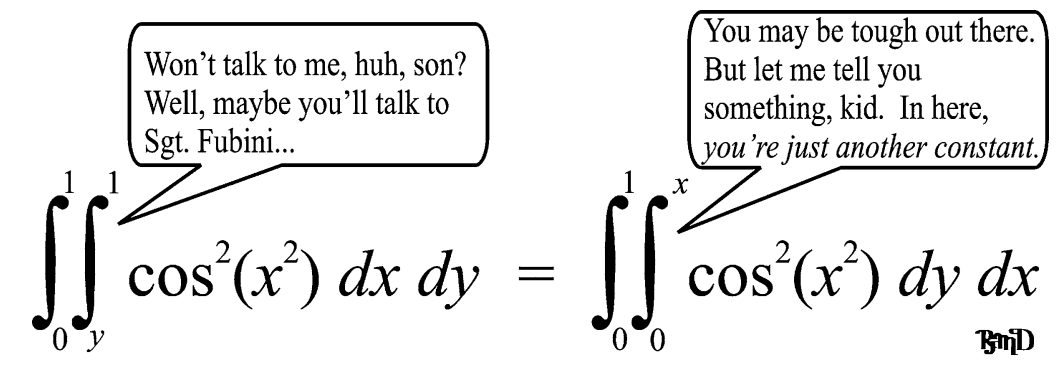

Department of Mathematics \& Computer Science St. Mary's University

Halifax, NS B3H 3C3

Canada

e-mail: rdawson@cs.stmarys.ca 